Send your letters to the Editor, British Dental Journal, 64 Wimpole Street, London W1G 8YS E-mail bdj@bda-dentistry.org.uk

Priority will be given to letters less than 500 words long. Authors must sign the letter, which may be edited for reasons of space. had written the obituary themselves before they died. They knew more about themselves than anyone else, and could ensure the inclusion (or omission) of any detail they considered essential. This then left the official obituarist with just a topping and tailing exercise, when the need for the obituary arose.

\section{N. James}

Hemel Hempstead the inevitable weak points of case numbers and selection. But... the standards discussed are essentially for dental alignment alone.

It would be unfair to refer to orthodontists as 'clinical technicians' but we have to accept that most current treatment is a blend of mechanics and surgery. The specialty is bored of my protestations concerning the risk of long-term damage to the teeth and face following this form of treatment, coupled with the high ratio of subsequent relapse. However, these risks are very real and if not addressed will eventually return to haunt us.

No one knows for certain the cause or cure of malocclusion but the soft tissues must be a frontrunner. Despite this, the concept that malocclusion should be corrected or improved, by changing posture or function receives far too little attention. The mechanical appliances so applauded by orthodontists may score high on dental alignment but actually increase vertical growth making long-term relapse and facial damage more likely.

Established bodies are universally slow at seeing their own faults but unless someone somewhere accepts that it is time for change, as my mother used to say, "It will end in tears".

\section{J. Mew \\ Purley}

\section{Obituary advice}

Sir,- I read with interest and a wry smile, Stephen Hancocks article on obituaries (BDJ 2003; 194: 176)

Having at one stage in my career been responsible for writing the obituaries of colleagues, I came to the conclusion that it would be best if the individuals concerned

\section{Use of common salt}

Sir,- Whatever the periodontal effects of common salt may be, your correspondent Mr R. Kitchen seems to disregard its influence on the corrosion of metals in the mouth.

Highly concentrated salt solutions are produced locally when grains of ingested salt dissolve in dental plaque. ${ }^{1}$ This process might partly explain differences in surface corrosion observed between similar amalgam restorations in different individuals.

\section{A. Cook}

London

1. Johansson B I, Lagerlöf F. Integrated currents between amalgams and a gold alloy in saline solutions and natural saliva with different chloride ion content Scand J Dent Res; 100: 240-243

\section{Survey considered}

Sir,- The recent survey by Gallagher and Wright ${ }^{1}$ gave an illuminating view of current attitudes towards employment of therapists in general dental practice. In fact the results of this recent survey can be used in conjunction with earlier research to show how great the shift in attitudes towards therapists has been.

In 1982 we were involved in a survey ${ }^{2}$ which asked dentists whether they would employ a dental therapist in a general practice. Only $38.5 \%$ of general practitioners answered yes and 61.5\% answered no. The recent research asked a similar question but gave the option of 3 responses yes, no and undecided. The raw percentages from the surveys are not comparable because the first survey did not allow an undecided category. To increase comparability we can remove the undecided responses in the new research: of the respondents who answered yes or no, $62.1 \%$ answered yes and 37.9\% answered no.

Naturally, we must be cautious in comparing surveys which differ in sampling techniques and in precise format. However, the figures indicate that the number of dentists who would employ a therapist in practice has increased very substantially (from 38.5\% to 62.1\%).

This suggests that the attitudes of general practitioners have shifted in line with the team approach advocated by recent government reports such as Options for Change. The changes in rules for employment of therapists approved by the GDC would appear timely as the dental profession appears ready to improve access to dental care through the new employment possibilities of dental therapists in the GDS and the expansion of dental therapist training.

\section{J. Woolgrove}

London

J. Boyle

Bristol

1. Gallagher J L, Wright D A. General dental practitioners knowledge of and attitudes towards the employment of dental therapists in general practice. Br Dent J 2003: 194: 37-41.

2. Woolgrove J, Harris R. Attitudes of dentists towards delegation. Br Dent J 1982; 153: 339-340.

\section{Non-retirement}

Sir,- I was delighted to see the letter from my old friend Dr Hokwerdah (BDJ 2003; 194: 120) with whom I worked in both the FDI and the ESDE for many years.

However, being still involved with editing, presenting lectures, seminars and part-time practice, may I make it clear that, to paraphrase Mark Twain, "reports of my retirement have been greatly exaggerated!"

Nevertheless, I hope Dr Hokwerdah will get a good response from UK dentists.

\section{E. Paul}

Edgware 